\title{
ISOLATION OF PROTEIN FROM THE SPINE VENOM OF PTEROIS VOLITANS FOUND IN THE INDONESIAN OCEAN, USING A HEATING PROCESS, FOR ANTICANCER, ANTIRETROVIRAL, ANTIBACTERIAL, AND ANTIOXIDANT ASSAYS
}

\author{
FERA IBRAHIM ${ }^{1}$, MUHAMAD SAHLAN ${ }^{2,3}$, MIKAEL JANUARDI GINTING ${ }^{4}$, DIAH KARTIKA PRATAMI ${ }^{5}$, HERI \\ HERMANSYAH $^{2}$, ANONDHO WIJANARKO ${ }^{2 *}$
}

\begin{abstract}
1 Virology and Cancer Pathobiology Research Centre, Faculty of Medicine, Universitas Indonesia, Dr. Cipto Mangunkusumo General Hospital, Jakarta, 10320, Indonesia, ${ }^{2}$ Department of Chemical Engineering, Faculty of Engineering, Universitas Indonesia, Depok, West Java, 16424, Indonesia, ${ }^{3}$ Research Centre for Biomedical Engineering, Faculty of Engineering Universitas Indonesia, Depok, West Java, 16424, Indonesia, ${ }^{4}$ Marine Science Postgraduate Program, Faculty of Mathematics and Natural Science, Universitas Indonesia, Depok, West Java, 16424, Indonesia, ${ }^{5}$ Laboratory of Pharmacognosy and Phytochemistry, Faculty of Pharmacy, Pancasila University, South Jakarta, 12640, DKI Jakarta, Indonesia

"Email: anondho.wijanarko@yahoo.com
\end{abstract}

Received: 06 Sep 2020, Revised and Accepted: 09 Oct 2020

\section{ABSTRACT}

Objective: This research investigates the antibacterial, anticancer, antioxidant, and antiretroviral activities of the lionfish spine poison extract.

Methods: Isolation and purification of the phospholipase A2 (PLA2) protein obtained from the spine poison were conducted through the following stages, including, extraction of the venom by sonication, heating, and purification using gradual saturation levels of ammonium sulfate. Furthermore, the purity and concentration of PLA2 were analyzed using the Lowry test and Marinetti's method, respectively, while its protein content was ascertained through SDS-PAGE. Toxicity was then evaluated employing the brine shrimp lethality test (BSLT), and its anticancer activity was assessed in human cervical carcinoma cells (HeLa cells). Finally, its antioxidant, antibacterial, and antiretroviral activities were analyzed using the DPPH method, agar diffusion test against Salmonella sp. and E. coli, and SRV-2 and RT-qPCR tests, respectively.

Results: The protein demonstrated 37.79\% inhibition for anticancer activity, IC 501312 ppm for antioxidant activity, 98.81\%, and 89.28\% inhibition of E. coli and Salmonella sp. respectively for antibacterial activity and $98.13 \%$ inhibition for antiretroviral activity.

Conclusion: It can be concluded that lionfish (Pterois volitans) has the potential to be developed as an antioxidant, anticancer, antibacterial, and antiretroviral agent. Furthermore, the pharmacological activity of its spine venom was determined by isolating PLA2 protein from its extract, using an optimum heating temperature of $70^{\circ} \mathrm{C}$ and an ammonium sulfate saturation level of $80 \%$.

Keywords: Pterois volitans, Crude venom, Anticancer, Antioxidant, Antibacterial, Antiretroviral

(C) 2021 The Authors. Published by Innovare Academic Sciences Pvt Ltd. This is an open access article under the CC BY license (http://creativecommons.org/licenses/by/4.0/) DOI: http://dx.doi.org/10.22159/ijap.2021.v13s2.10 Journal homepage: https://innovareacademics.in/journals/index.php/ijap

\section{INTRODUCTION}

Pterois volitans commonly known as Lionfish are a predator species that hunts its prey such as crustaceans, small fishes, and crabs at night because it is nocturnal [1]. Although they may look unique and have an attractive shape, they sit at the top of the food chain in the ocean because their sting is a threat to other marine life-forms [2]. Reports have shown that they are capable of damaging coral reefs and altering the food chain, therefore causing imbalances in the ecosystem, which leads to population changes [3, 4]. Consequently, this fish can pose a threat to the marine life forms in countries that are close to the Indo-Pacific Ocean, which lies adjacent to the Indian Ocean, of which Indonesia is one such [5].

The thorns of lionfishes produce highly toxic venom, which on entering a victim first induces a burning sensation that lasts for about 15-20 min, then limb paralysis within $3 \mathrm{~h} \mathrm{[6]} \mathrm{and} \mathrm{sometimes}$ cardiovascular, neuromuscular, and cytolytic effects which can lead to cell death. Moreover, its poisonous effect is abetted by the presence of toxic proteins and other active components, such as pore-forming venoms and acetylcholine [7]. Nevertheless, this poison has the potential to be used for beneficial purposes.

Another fish that happens to be related to this fish and also produces poison containing PLA2 that is believed to possess antibacterial activity is $P$. russelii $[8,9]$. Moreover, the poison of lionfishes also expresses anticancer, antioxidant, and antiretroviral activities [10].

PLA2 proteins can be isolated from the poison of this fish using the extraction method as follows: A sonicator is applied to the poisons using a phosphate buffer solution [11], then the mixture is heated, and purified by precipitation using ammonium sulfate [12].

\section{MATERIALS AND METHODS}

\section{Materials sample}

The spine venom of $P$. Volitans spine found in the Indonesian Ocean was used in this research.

\section{Sample preparation and venom extraction}

The preparation of samples was carried out according to the method reported by Savitri et al. [12], which involved first the cutting of the spines of the lionfish under cold conditions, and then rinsing them in $0.01 \mathrm{M}$ phosphate buffer $(\mathrm{pH}$ 7.0). $50 \mathrm{~g}$ of the spines were submerged in phosphate buffer ( $\mathrm{pH}$ 7.0) containing $\mathrm{CaCl}_{2}$, and an extract was prepared by sonication for $2 \times 8$ min with $80 \%$ pulses and an output of 10 at $20 \mathrm{kHz}$, during which the cold temperature conditions were maintained. Centrifiguration of the extract was then carried out at temperatures of $4{ }^{\circ} \mathrm{C}$ and a speed of $4500 \mathrm{rpm}$. The resultant extract was then dissolved and named 'crude venom (CV)'.

\section{Venom protein isolation}

Proteins were isolated following to procedures reported by Sommeng et al. [13], which involved first the heating of the CV sample at temperature variations of $50^{\circ} \mathrm{C}, 55^{\circ} \mathrm{C}, 60^{\circ} \mathrm{C}, 65^{\circ} \mathrm{C}$, and 70 ${ }^{\circ} \mathrm{C}$ for $30 \mathrm{~min}$ to determine the optimum results of protein purity, and then, centrifuging it at $4500 \mathrm{rpm}$ for $30 \mathrm{~min}$.

Purification was then conducted following a method called ammonium sulfate fractionation. This method involved the addition of small amounts of ammonium sulfate to the pre-heated venom with the saturation of $20 \%, 40 \%, 60 \%$, and $80 \%$. Afterward, centrifugation was carried out for $30 \mathrm{~min}$ and at speeds of 4500 
rpm, and the resultant sediments were submerged in a $0.01 \mathrm{M}$ phosphate buffer solution ( $\mathrm{pH} 7.0$ ) which contained $0.001 \mathrm{M} \mathrm{CaCl}_{2}$.

\section{Determination of protein concentration}

Lowry method which involved the used of both a $0.5 \mathrm{ml}$ of FolinCiocalteu phenol $1 \mathrm{~N}$ Folin reagent and a biuret solution $(1 \mathrm{ml}$ of $1 \%$ $\mathrm{CuSO}_{4}$ and NaK-tartrate solution each in $100 \mathrm{ml}$ of $2 \% \mathrm{Na}_{2} \mathrm{CO}_{3}$ in 0.1 $\mathrm{N} \mathrm{NaOH}$ ) were used to ascertain the concentration of protein contained in the sample [14]. Besides, using $200 \mu \mathrm{g} / \mathrm{ml}$ of bovine serum albumin (BSA), the standard curves were plotted. Lastly, the absorbance values of the sample were measured using an ultraviolet-visible (UV-VIS) spectrophotometer, at a wavelength of $750 \mathrm{~nm}$.

\section{PLA2 activity}

The Marinetti method was imployed after the determination of the protein concentration in other to investigate the activity of the PLA2 protein using the enzymatic activity of the yolk of an egg [15]. Meanwhile, this as conducted because a type of lecithin in which the data is the substrate for the PLA2 enzyme or phosphatidylcholine protein is found in egg yolk. Nevertheless, using the UV-VIS spectrophotometer for $5 \mathrm{~min}$ and at a wavelength of $900 \mathrm{~nm}$, it was observed that there was a reduction in the absorbance value without the addition of the enzyme sample.

\section{Anticancer test using MTT assay}

Through the MTT assay, using HeLa Cells, the anticancer effect of this venom sample was evaluated according to the instruction of the CellTiter $96^{\circ}$ Non-Radioactive Cell Proliferation Assay [16]. Furthermore, the reagent used was Promega G400.

Dilution of both the heated $\left(50^{\circ} \mathrm{C}, 55^{\circ} \mathrm{C}, 60^{\circ} \mathrm{C}, 65^{\circ} \mathrm{C} 70^{\circ} \mathrm{C}\right)$ and the CV samples were conducted using PenStrep, DMEM, and $0.5 \%$ FBS solution, and the resultant samples were at concentrations of 2, 250, 500 and 2500 ppm. Furthermore, seeding of the $2 \times 10^{4} \log$-phase HeLa cells into 96-wells was conducted, and then incubation was carried out for $24 \mathrm{~h}$ before treatment with the samples of the venom. Next, the cells were incubated for another $20 \mathrm{~h}$ and using the MTT dye solution; they were all dyed. Following suit was another set of incubation, which lasted for $4 \mathrm{~h}$ before the stop solution was added. Afterward, at about $1 \mathrm{~h}$ later, using the ELISA reader at a wavelength of $595 \mathrm{~nm}$, the absorbance values were ascertained, and all the above treatments were carried out in duplicate wells. Finally, it needs to be noted that the anticancer effect was of the venom was ascertained by calculating the rate of inhibition.

\section{Antioxidant activity assay using DPPH}

Credit goes to Sommeng et al. for describing the antioxidant determining method used in this research [17]. The method involved first preparing a solution of DPPH at a concentration of 125 $\mu \mathrm{M}$ by weighing $2.5 \mathrm{mg}$ DPPH in $50 \mathrm{ml}$ of ethanol and covering it with an aluminum foil. Next, adjusting the concentration of the solution to $20 \mathrm{ppm}$ and adding $100 \mu \mathrm{l}$ of the sample and DPPH solution to a microplate. Finally, preparing a blank using $200 \mu \mathrm{l}$ of ethanol and covering the microplate with an aluminum foil before incubating for $30 \mathrm{~min}$. The blank solution and sample were then analyzed using a microplate ELISA reader at a wavelength of $517 \mathrm{~nm}$ to ascertain their absorbance values, which were later plotted into the following Equation 1, to obtain the inhibition value [18]:

$$
\text { \%inhibition }=\frac{\text { blank absorbance }- \text { sample absorbance }}{\text { blank absorbance }} \times 100 \%
$$

First, the graph of line equation was plotted from the percentage inhibition obtained for each sample, and then the resulting equation was obtained using the value $\mathrm{x}\left(\mathrm{IC}_{50}\right)$ by changing the value of $\mathrm{y}=50$ [19]. All these were carried out to obtain the $\mathrm{IC}_{50}$ value.

\section{Antibacterial activity test}

Following the method described by Wiegand et al., the venom was investigated for its antibacterial activity, using the agar dilution method, and based on the minimum inhibitory concentration [20].
Moreover, E. coli and Salmonella sp were the two species of bacterial tested.

For $24 \mathrm{~h}$, the Inoculums of both bacterial were prepared to obtain a concentration of $25 \%$. Next, they were diluted to concentrations of $10^{3} \mathrm{CFU} / \mathrm{ml}$, and the sample (both the positive $(\mathrm{C}+)$ and negative control ( $\mathrm{C}-\mathrm{J})$ was then prepared by adding into each sterile containers, $100 \mu \mathrm{l}$ of the inoculum.

To prepare the positive control, $10 \mathrm{mg}$ of chloramphenicol was added to $10 \mathrm{ml}$ to make a concentration of $1000 \mathrm{ppm}$, which was then used for both bacteria. Furthermore, the negative controls for both bacteria were prepared by adding $100 \mu \mathrm{l}$ aq. Sterile into the Eppendorf tube. The samples ( $\mathrm{C}+$ and C-), each at a volume of $100 \mu \mathrm{l}$ in the Eppendorf tube were then added to the bacterial inoculum $\left(10^{3} \mathrm{CFU} / \mathrm{ml}\right)$ and homogenized by vortexing. Afterward, $100 \mu \mathrm{l}$ each of the samples and controls was collected into sterile Petri dishes, and $20-25 \mathrm{ml}$ of TSA was added to them. The mixture was then homogenized and incubated at $30{ }^{\circ} \mathrm{C}-35{ }^{\circ} \mathrm{C}$ for $24 \mathrm{~h}$. Finally, the growth of Bacterial was observed, and the minimum inhibitory concentration was determined when the Petri dish was not completely overgrown with microbes. Meanwhile, the particular area of the chromatogram shows the inhibition of bacterial growth.

\section{Antiretroviral activity test using SRV-2}

To ascertain the antiretroviral activity, three tests as follows: MTT assay, RT-qPCR test, and antiretroviral activity SRV-2 test were conducted $[21,22]$. Meanwhile, the MTT assay aims to ascertain how toxic the sample is to the human A549 cells (lung cancer cells) that were prepared in the Dulbecco's modified Eagle's medium (DMEM), which contained $100 \mu \mathrm{g} / \mathrm{ml}$ streptomycin, $5 \%$ fetal bovine serum (FBS), and $1000 \mathrm{U} / \mathrm{ml}$ penicillin.

The cells were first grown at concentrations of 5000 cells in $100 \mu \mathrm{l}$, and later $(24 \mathrm{~h})$, into them was added the extract, when the cell confluence was at $50 \%$. Then, on the third day, to carry out the MTT test, MTT at a concentration of $5 \mathrm{mg} / \mathrm{ml}$, and a volume $10 \mu \mathrm{l}$ was added to each well, and the mixture was incubated at $37^{\circ} \mathrm{C}$ for $4 \mathrm{~h}$, while the formazan crystals were dissolved in ethanol. Furthermore, after heating $20 \mathrm{~m}$ of the sample for $20 \mathrm{~min}, 25 \mathrm{~m}$ for $25 \mathrm{~min}, 30 \mathrm{~m}$ for $30 \mathrm{~min}$ and $35 \mathrm{~m}$ for $35 \mathrm{~min}$, and adding $0.5 \mathrm{ml}$ and $1.5 \mathrm{ml}$ of caprylic acid $(20 \mathrm{~m}, \mathrm{CA} 0.5 \mathrm{ml})$, six types of sedimentation samples of $20 \%$ ammonium sulfate were obtained, and this test was conducted on them. Finally, the samples were tested using four concentration variations, including $1,2,3$, and 4 ppm in triplicate.

\section{RESULTS AND DISCUSSION}

\section{The effect of heating temperature on protein concentration}

It can be seen from the results, as shown in fig. 1 that temperature is directly proportional to the concentration of the resulting protein. Therefore, with an increase in the heat, the more concentrated the protein produced is. Furthermore, fig. 2 shows the effect of temperature on the specific activity of this protein, and it suggests that the activity of the sample increases with an increase in heating time.

It was discovered the heating temperature affects protein concentration, as it increases caused a simultaneous rise in the concentration of protein produced. Therefore, it confirms that a higher heating temperature caused the isolation of more protein because the proteins which are denatured during heating get accumulated during fractionation using ammonium sulfate [13]. Furthermore, an increase in the cycles of fractionation using ammonium sulfate at higher saturation levels causes the isolation of lower concentrations of protein [23]. Lastly, it confirms that more stages of fractionation using ammonium sulfate would lead to the isolation of less protein, and this is because the maximum amount of protein could have been isolated during the previous fractionation stages using ammonium sulfate, just as it was observed with $0 \%$ $20 \%$ ammonium sulfate saturation. Meanwhile, according to Matulis (2016), ammonium sulfate fractionation stages can cause the production of protein in a more pure form [24]. 


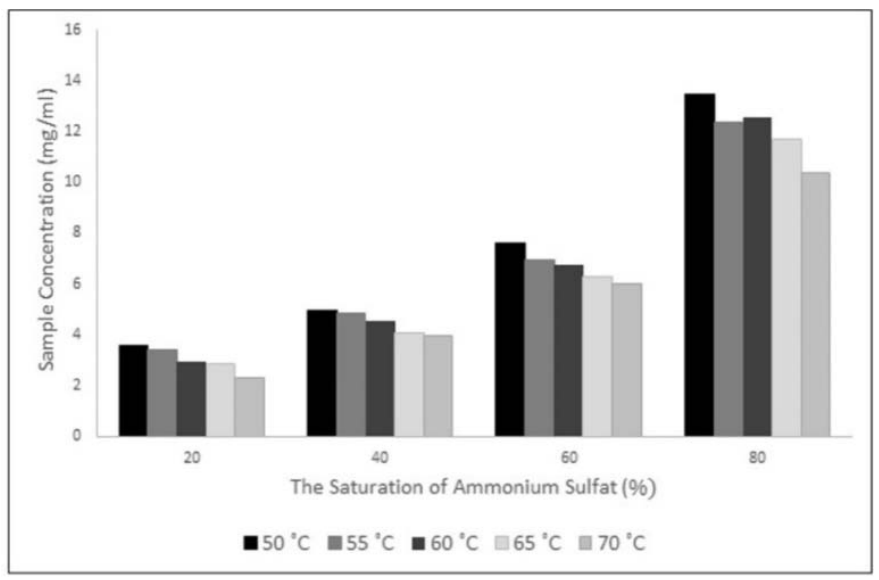

Fig. 1: The effect of heating temperature on sample concentration

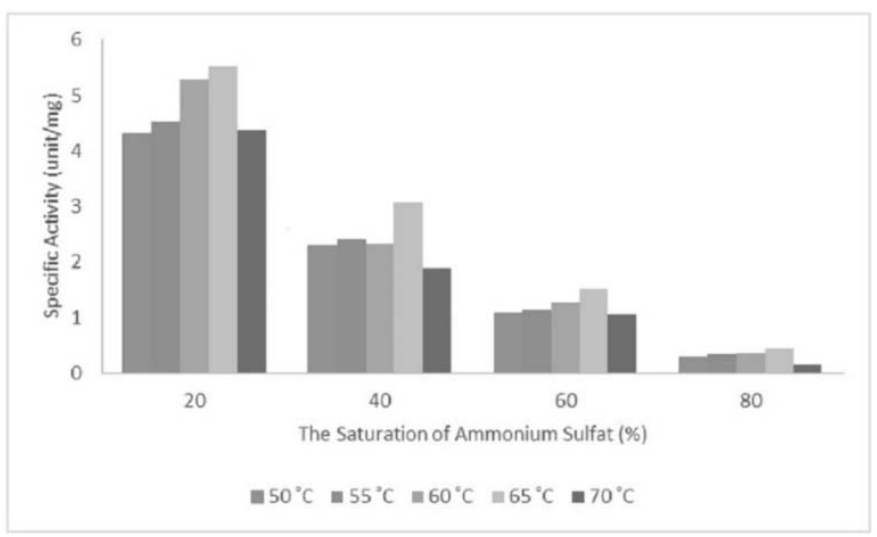

Fig. 2: The effect of heating temperature on the specific activity of PLA2

PLA2 activity was found to increase with every rise in heating temperature. Furthermore, a more effective was to obtain pure protein from the extract of Lionfish venom is through heating [16] The CV obtained after heating at $70^{\circ} \mathrm{C}$, and fractionation using $80 \%$ ammonium sulfate, can potentially be developed into an anticancer agent since, at $750 \mathrm{ppm}$, it resulted in $37.79 \%$ inhibition. Furthermore, phospholipase A2 protein was found to be affected by the duration of heating.

\section{Anticancer activity of Pterois volitans spine venom}

To enhance the results, the samples were investigated for cytotoxic Anti-cervical cancer activity, using the MTT method. Moreover, according to Sommeng (2019), the values of inhibition increases with every increase in temperature and concentration [16]. Fig. 3 shows the effect of heating temperature on the inhibition of HeLa cells.

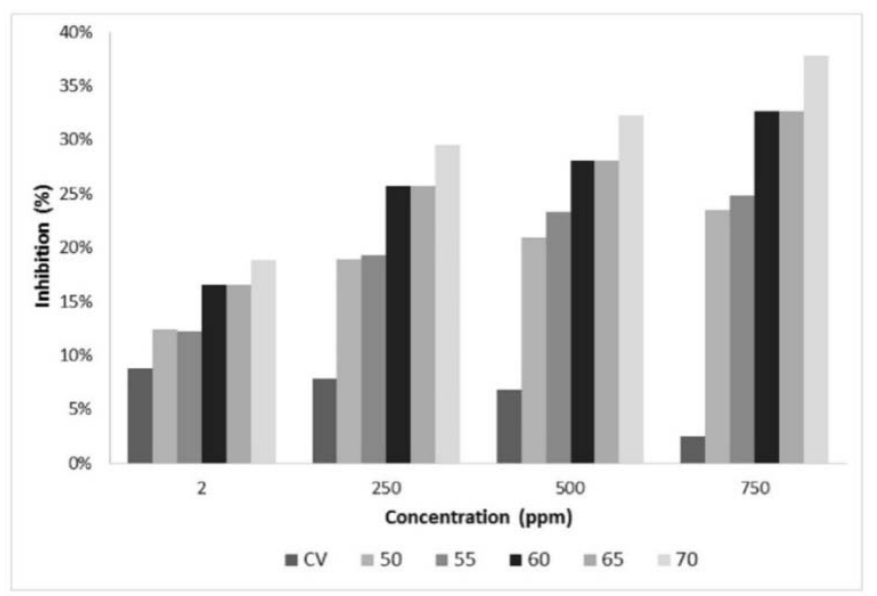

Fig. 3: The effect of heating temperature on the inhibition of HeLa cells 
The investigation of the cytotoxic Anti-cervical cancer activity of PLA2 through the MTT procedure aims to ascertain the toxicity of this protein by observing whether it induces a reduction in cell viability. Furthermore, as reported in previous research by Raetz and Dowhan (1990), this procedure is colorimetric and is based on alterations in these tetrazolium salts (3-(4,5-dimethylthiazol-2-yl)2,5-diphenyltetrazolium bromide (MTT), changing into formazan in the mitochondria of living cells [25]. Purple formazan crystals are then formed after the degradation of MTT, and the number formed denotes the rate of cell inhibition. Moreover, the inhibition values increase with an increase in concentration and temperature [16].

HeLa cells are affected by heating. Meanwhile, the heating process is an effective procedure used in obtaining purer protein samples from the extract of lionfish venom. The $\mathrm{CV}$, which was isolated by heating at $70{ }^{\circ} \mathrm{C}$, and fractionated using ammonium sulfate (AS) at a saturation level of $80 \%$ can potentially be developed into an anticancer agent because at $750 \mathrm{ppm}$ it resulted in $37.79 \%$ inhibition. Moreover, the results of the SDS PAGE analysis showed that this fish ( $P$. volitans) has several proteins which can cause an apoptotic effect on HeLa cells. This occurs when the toxin from the venom of this fish activates caspase-8, which in turn activates procaspase- 3 that leads to the stimulation of caspase- 3 activation [26]. The caspase cascade activation then causes the fragmentation of DNA. Meanwhile, during the apoptotic process, a specific nuclease cuts genomic DNA between the nucleosome to obtain DNA fragments, and these fragments serve as markers that help in the identification of cells that die from apoptosis [27].

\section{Antioxidant activity of Pterois volitans spine venom}

The number of saturation demands needed for fractionation using ammonium sulfate is influenced by several factors, one of which is the heating temperature (fig. 3). Furthermore, a temperature of $75^{\circ} \mathrm{C}$ and ammonium sulfate with concentrations of $40 \%-60 \%$ was found to be the best conditions for this assay because they caused the highest inhibition (76.13\%). Therefore, it can be suggested that proteins isolated at this temperature have the highest antioxidant activity. The $\mathrm{IC}_{50}$ values obtained from each sample can be seen in table 1.

Table 1: IC 50 values obtained from each sample

\begin{tabular}{|c|c|c|c|c|}
\hline \multirow[t]{3}{*}{ Variable } & \multicolumn{4}{|c|}{$\mathrm{IC}_{50}(\mathrm{ppm})$} \\
\hline & \multicolumn{4}{|c|}{ Heating temperature $\left({ }^{\circ} \mathrm{C}\right)$} \\
\hline & $25(\mathrm{CV})$ & 60 & 75 & 90 \\
\hline AS $0 \%$ & 13888.890 & 11627.910 & 4504.505 & 4672.897 \\
\hline AS $0 \%-20 \%$ & 15625.000 & 8474.576 & 2857.143 & 3731.343 \\
\hline AS $20 \%-40 \%$ & 10204.080 & 7246.377 & 2325.581 & 12820.510 \\
\hline AS $40 \%-60 \%$ & 8474.576 & 3472.222 & 1312.336 & 38461.540 \\
\hline AS $60 \%-80 \%$ & 3623.188 & 1742.160 & 6172.840 & 71428.710 \\
\hline
\end{tabular}

The heating temperature affects the number of saturation requirements needed in fractionation using ammonium sulfate. Furthermore, the greatest inhibition percentage value of $76.13 \%$ was observed in samples that were heated at a temperature of $75{ }^{\circ} \mathrm{C}$ and a saturation level of $40 \%-60 \%$ of ammonium sulfate. This value shows that the best temperature for demonstrating the antioxidant activity of this venom is $75^{\circ} \mathrm{C}$. Furthermore, following the ammonium sulfategrade fractionation, the most effective isolated protein was at $40 \%$ $60 \%$ ammonium sulfate saturation [17]. Therefore, a combination of the following is the best conditions for the proteins to be isolated: an ammonium sulphate saturation level of $40 \%-60 \%$, and a heating temperature of $75{ }^{\circ} \mathrm{C}$, including an $\mathrm{IC}_{50}$ value of $1312 \mathrm{ppm}$. Nevertheless, this $\mathrm{IC}_{50}$ value was the least requirement since it was obtained at $>200 \mathrm{ppm}$ [28]. Meanwhile, it was similar to what was obtained by Sommeng (2019), which reported a value 1563.06 ppm, which shows a greater antioxidant activity [17].
At this optimum isolation temperature, which also supports maximum antioxidant activity, the protein composition was 7.9, 46.2 and $52.7 \mathrm{kD}$. Moreover, for every change in temperature, a new saturation of ammonium sulphate is needed.

\section{Antibacterial activity of Pterois volitans spine venom}

It can be seen in table 2, which shows the results of the antibacterial activity test that a saturation level of AS80\% is necessary for samples to inhibit bacterial growth; therefore, it can be suggested that saturation has an influence on the antibacterial activity of the samples. Meanwhile, the most potent concentration of the $35 \mathrm{~m}$ sample was $3.77 \mu \mathrm{g} / \mathrm{ml}$. Furthermore, it inhibited $98.81 \%$ of E. coli activity, which is very close to the LD99\%, and $89.28 \%$ of Salmonella sp. activity, which is also very close to LD 90\%. Therefore, PLA2 from the venom of lionfish can potentially be developed into an antibacterial agent.

Table 2: Antibacterial activity test results

\begin{tabular}{llll}
\hline Sample & \multicolumn{2}{l}{ Number of colonies of $\boldsymbol{E}$. coli $(\mathbf{C F U} / \mathbf{1 0 0} \boldsymbol{\mu l})$} & Number of colonies of Salmonella sp. (CFU/100 $\boldsymbol{\mu l}$ ) \\
\cline { 2 - 4 } & I & II & I \\
\hline AS 20\%, 35m & $>300$ & $>300$ & $>300$ \\
AS 40\%, 40m & $>300$ & $>300$ & $>300$ \\
AS 60\%, 40m & $>300$ & $>300$ & $>300$ \\
AS 80\%, 30m & 116 & 96 & 317 \\
AS 80\%, 35m & 23 & 48 & 338 \\
AS 80\%, 40m & 142 & 101 & 321 \\
K+(Chloramphenicol 1000 ppm) & 0 & 0 & 0 \\
K-(Sterile Aq.) & $2.4 \times 10^{2}$ & $2.1 \times 10^{2}$ & 300 \\
\hline
\end{tabular}

Since the samples with saturations of AS80\% inhibits bacterial multiplication, it can be suggested that saturation has a role to play in antibacterial activity. Furthermore, the E. coli bacteria was significantly impacted when compared to Salmonella $s p$. because a large amount of phospholipid in its cell membrane is phosphatidylethanolamine, which is a preferred substrate by the PLA2, even though this enzyme is not substrate-specific [29]. Comparatively, the venom obtained from Naja naja, commonly known as Indian cobra, was found to be more potent at a lower concentration of $19.3 \mu \mathrm{g} / \mathrm{ml}$ for E. coli and $22.1 \mu \mathrm{g} / \mathrm{ml}$ for Salmonella $s p[29]$.

Due to the myotoxic activities of phospholipids A2 homologs proteins, their potential antimicrobial activity has been studied [30]. Therefore, PLA2 can potentially be developed as an antibacterial agent. 


\section{Antiretroviral activity test using SRV-2}

It can be seen in table 3, which shows the result of the antiretroviral activity SRV-2 test, that at concentrations of $1-4 \mathrm{ppm}$, the $20 \mathrm{~m} \mathrm{CA}$ $0.5 \mathrm{ml}$ sample caused a significant reduction in the viral activity when compared to the negative controls. This reduction was found to be at $98.13 \%$ inhibition, which is very similar to that of the positive control where lamivudine $100 \mathrm{ppm}$ was used, and which showed inhibition of $99.51 \%$. It was also purified using the purification method, which involved salting with $20 \%$ ammonium sulfate and acidifying with $0.5 \mathrm{ml}$ caprylic acid by heating at a temperature of $60{ }^{\circ} \mathrm{C}$ for $20 \mathrm{~min}$. Finally, it caused a greater inhibition compared to the $30 \mathrm{~m}$ sample, which was purified as stated above, but without acidification with caprylic acid by heating at a temperature of $60{ }^{\circ} \mathrm{C}$ for $30 \mathrm{~min}$, as this showed inhibition of $88.01 \%$.

Table 3: Summary of preliminary test results of the isolation of phospholipase A2

\begin{tabular}{llll}
\hline No & Sample & Copy number & \%Inhibition \\
\hline 1 & Negative Control & $3,942,355$ & $0 \%$ \\
2 & Positive Control (Lamivudine 100 ppm) & 18,973 & $99.51 \%$ \\
3 & $20 \mathrm{~m} \mathrm{CA} \mathrm{0.5} \mathrm{ml} \mathrm{1} \mathrm{ppm}$ & 645,344 & $83.63 \%$ \\
4 & $20 \mathrm{~m} \mathrm{CA} \mathrm{0.5} \mathrm{ml} \mathrm{2} \mathrm{ppm}$ & 533,727 & $86.46 \%$ \\
5 & $20 \mathrm{~m} \mathrm{CA} \mathrm{0.5} \mathrm{ml} \mathrm{3} \mathrm{ppm}$ & 290,223 & $92.63 \%$ \\
6 & $20 \mathrm{~m} \mathrm{CA} \mathrm{0.5} \mathrm{ml} \mathrm{4} \mathrm{ppm}$ & 73,593 & $98.13 \%$ \\
7 & $30 \mathrm{~m} \mathrm{1} \mathrm{ppm}$ & 775,363 & $80.33 \%$ \\
8 & $30 \mathrm{~m} \mathrm{2} \mathrm{ppm}$ & 583,224 & $85.20 \%$ \\
9 & $30 \mathrm{~m} \mathrm{3} \mathrm{ppm}$ & 556,011 & $85.59 \%$ \\
10 & $30 \mathrm{~m} \mathrm{4} \mathrm{ppm}$ & 472,334 & $88.01 \%$ \\
\hline
\end{tabular}

A greater percentage for the inhibition of Simian retrovirus serotype-2 was observed when compared to that reported by Ramadhan (2018), which showed that there was 97\% inhibition using the purification method of ammonium sulfate salting gradually at a saturation level of $80 \%$ [22]. This suggests that the $20 \mathrm{~m}$ sample has better antiretroviral activity when compared to that of lamivudine, and also, it has capabilities that are not much different from those of standard antiretroviral drugs available on the market. The potential of antiretroviral from natural product medicine must be monitored its side effects by appropriate monitoring [31].

\section{CONCLUSION}

In this research, the potential of the lionfish spine venom to be developed as an anticancer, antioxidant, antibacterial, and antiretroviral agent was determined by isolating the PLA2 protein from the venom extract. Furthermore, an optimum heating condition of $70^{\circ} \mathrm{C}$ and an ammonium sulfate saturation level of $80 \%$ was used for the isolation of proteins that have the potential pharmacological activity. Lastly, the results showed $37.79 \%$ inhibition for anticancer activity, $\mathrm{IC}_{50} 1312 \mathrm{ppm}$ for antioxidant activity, $98.81 \%$, and $89.28 \%$ inhibition of E. coli and Salmonella sp. respectively for antibacterial activity and $98.13 \%$ inhibition for antiretroviral activity.

\section{ACKNOWLEDGEMENT}

This research and article's publication is supported by the Grant of Indexed International Publication (Publikasi Internasional Terindeks-PIT 9) funded by Universitas Indonesia No. NKB0043/UN2. R3.1/HKP.05.00/2019.

\section{FUNDING}

Funding from DRPM Universitas Indonesia

\section{AUTHORS CONTRIBUTIONS}

All the authors have contributed equally.

\section{CONFLICT OF INTERESTS}

The authors declare no conflict of interest.

\section{REFERENCES}

1. Ritger AL, Fountain CT, Bourne K, Martin Fernandez JA, Pierotti MER. Diet choice in a generalist predator, the invasive lionfish (Pterois volitans/miles). J Exp Mar Bio Ecol 2020;524:151311.

2. Eddy C, Pitt J, Oliveira K, Morris JA, Potts J, Bernal D. The life history characteristics of invasive lionfish (Pterois volitans and P. miles) in Bermuda. Environ Biol Fishes 2019;102:887-900.

3. Albins MA. Invasive pacific lionfish Pterois volitans reduce the abundance and species richness of native bahamian coral-reef fishes. Mar Ecol Prog Ser 2015;522:231-43.
4. Cote IM, Maljkovic A. Predation rates of Indo-pacific lionfish on Bahamian coral reefs. Mar Ecol Prog Ser 2010;404:219-25.

5. Kulbicki M, Beets J, Chabanet P, Cure K, Darling E, Floeter SR, et al. Distributions of Indo-Pacific lionfishes Pterois spp. in their native ranges: implications for the atlantic invasion. Mar Ecol Prog Ser 2012;446:189-205.

6. Vetrano SJ, Lebowitz JB, Marcus S. Lionfish envenomation. J Emerg Med 2002;23:379-82.

7. Church JE, Hodgson WC. The pharmacological activity of fish venoms. Toxicon 2002;40:1083-93.

8. Memar B, Jamili S, Shahbazzadeh D, Bagheri KP. The first report on coagulation and phospholipase A2 activities of persian gulf lionfish, Pterois russelli, an Iranian venomous fish. Toxicon 2016;113:25-31.

9. Nevalainen TJ, Graham GG, Scott KF. Antibacterial actions of secreted phospholipases A2 review. Biochim Biophys Acta (BBA)-Molecular Cell Biol Lipids 2008;1781:1-9.

10. Cipolari OC, de Oliveira Neto XA, Conceicao K. Fish bioactive peptides: a systematic review focused on sting and skin. Aquaculture 2019;515:734598.

11. Savitri IKE, Ibrahim F, Sahlan M, Wijanarko A. Rapid and efficient purification method of phospholipase A2 from Acanthaster planci. Int J Pharm Biosci 2011:2:401-6.

12. Savitri IKE, Sahlan M, Ibrahim F, Wijanarko A. Isolation and characterization of phospholipase A2 from the spines venom of the crown-of-thorns starfish isolated from papua island. Int J Pharma Bio Sci 2012;3:603-8.

13. Sommeng AN, Pratiwi I, Ginting MJ, Sahlan M, Hermansyah $\mathrm{H}_{\text {, }}$ Wijanarko A. The effects of heating process on protein isolation of lionfish (Pterois volitans) spines venom extract to antioxidant activity assay. In: AIP Conference Proceedings 2019;2193:20007.

14. Dawson JM, Heatlie PL. Lowry method of protein quantification: evidence for photosensitivity. Anal Biochem 1984;140:391-3.

15. Marinetti GV. The action of phospholipase a on lipoproteins. Biochim Biophys Acta Lipids Lipid Metab 1965;98:554-65.

16. Sommeng AN, Sari M, Ginting MJ, Sahlan M, Hermansyah $H_{,}$ Wijanarko A. The influence of heating process on anticancer activity of Pterois volitans (red lionfish) venom extraction against human cervical carcinoma cell. In: AIP Conference Proceedings 2019;2193:03002217.

17. Sommeng AN, Larasati R, Ginting MJ, Pebriani S, Sahlan M, Hermansyah $\mathrm{H}$, et al. Extraction, antioxidant, and bioactive component assay of lionfish venom Pterois volitans. In: AIP Conference Proceedings 2019;2193:030008.

18. Molyneux P. The use of the stable free radical diphenylpicrylhydrazyl (DPPH) for estimating antioxidant activity. Songklanakarin J Sci Technol 2004;26:211-9.

19. Sharma P, Kumar P, Sharma R, Dhot PS. Futuristic scope of stem cells in medicine. Asian J Pharm Clin Res 2016;9 Suppl 1:13-6. 
20. Balouiri M, Sadiki M, Ibnsouda SK. Methods for in vitro evaluating antimicrobial activity: a review. J Pharm Anal 2016;6:71-9.

21. Sommeng AN, Tafsili MAB, Ginting MJ, Sahlan M, Hermansyah $\mathrm{H}$, Wijanarko A. Utilization of lionfish (Pterois volitans) venomous spines with effective purification as an alternative antiretroviral HIV/AIDS. AIP Conference Proceedings 2019;2193:30016.

22. Sommeng AN, Arya RMY, Ginting MJ, Pratami DK, Hermansyah $\mathrm{H}$, Sahlan $\mathrm{M}$, et al. Antiretroviral activity of Pterois volitans (red lionfish) venom in the early development of human immunodeficiency virus/acquired immunodeficiency syndrome antiretroviral alternative source. Vet World 2019;12:309-15.

23. Sommeng AN, Eka AK, Ginting MJ, Pebriani S, Sahlan M, Hermansyah $\mathrm{H}$, et al. The effect of ammonium sulfate concentration in protein isolation of lionfish (Pterois volitans) spines venom extract for antitumor test. AIP Conference Proceedings 2019;2193:30009.

24. Matulis D. Selective precipitation of proteins. Curr Protoc protein Sci 2016;83:4-5.

25. Raetz CR, Dowhan W. Biosynthesis and function of phospholipids in Escherichia coli. J Biol Chem 1990:265:1235-8.
26. Rogers C, Erkes DA, Nardone A, Aplin AE, Fernandes Alnemri T, Alnemri ES. Gasdermin pores permeabilize mitochondria to augment caspase-3 activation during apoptosis and inflammasome activation. Nat Commun 2019;10:1-17.

27. Dahham SS, Al-Rawi SS, Ibrahim AH, Majid ASA, Majid AMSA. Antioxidant, anticancer, apoptosis properties and chemical composition of black truffle Terfezia claveryi. Saudi J Biol Sci 2018;25:1524-34.

28. Li H, Zhang Z, Li M, Li X, Sun Z. Yield, size, nutritional value, and antioxidant activity of oyster mushrooms grown on perilla stalks. Saudi J Biol Sci 2017;24:347-54.

29. Sudarshan S, Dhananjaya BL. Antibacterial activity of an acidic phospholipase A2 (NN-XIb-PLA 2) from the venom of Naja naja (Indian cobra). Springerplus 2016;5:112.

30. Diniz Sousa R, Caldeira CAS, Kayano AM, Paloschi MV, Pimenta DC, Simoes Silva R, et al. Identification of the molecular determinants of the antibacterial activity of lmut TX, a Lys49 phospholipase A2 homologue isolated from Lachesis muta muta snake venom (Linnaeus, 1766). Basic Clin Pharmacol Toxicol 2018;122:413-23.

31. Sari SP, Isnaini SR, Puspitasari AW. Monitoring side effects of antiretroviral therapy in patients with human immunodeficiency virus/acquired immunodeficiency syndrome. Int J Appl Pharm 2018;10 Special Issue 1:321-4. 